\title{
THE HETTNER-HARTSHORNE CONNECTION: RECONSIDERING THE PROCESS OF RECEPTION AND TRANSFORMATION OF A GEOGRAPHIC CONCEPT
}

\author{
FRANCIS HARVEY ${ }^{1}$ \\ UTE WARDENGA ${ }^{2}$
}

\begin{abstract}
This contribution examines the process of reception and transformation of a geographic concept on the example of the connection between Alfred Hettner and Richard Hartshorne. The first part sketches the development and structure of Hettner's theoretical construction of geography. This examination shows that commonly held perceptions until now are the results of a reception that only partially, and in parts erroneously, represent Hettner's thinking. The second part illustrates how Richard Hartshorne received Hettner's concept. Hartshorne, like Hettner's German colleagues, did not grasp the underlying meaning of Hettner's work. However, in contrast to many German geographers, he did understand important aspects of Hettner's approach, like, for example, the relational approach to the "region", the problem of regionalization, and the relationship between idiography and nomothesis. The third part shows how German geographers' understanding of Hettner's concept was influcenced by the Hartshorne-Schaefer debate in the 1970s.
\end{abstract}

Key-words: Hettner, Hartshorne, Allgemeine Geographie, Länderkunde, idiographic, nomothesis, Hartshorne-Schaefer debate.

Résumé: LA CONNEXION HeTtNeR-HARTSHORNE: RECONSIDERATION DU PROCESSUS DE RECEPTION ET DE TRANSFORMATION D'UNE CONCEPTION DE LA GEOGRAPHIE - Ce texte examine le processus de réception et de transformation d'une conception de la géographie en prenant l'exemple de la connexion entre Alfred Hettner et Richard Hartshorne. Dans la première partie les auteurs résument le développement et la structure de la construction théorique de Hettner. Cette révision prouve que les idées reçues sur la conception de la géographie de Hettner sont le résultat d'une interprétation erronée et partiale de sa pensée. La seconde partie examine la façon dont Richard Hartshorne reçut la conception de Hettner. Comme dans le cas des contemporains

1 EPFL-IGEO Lausanne, Switzerland.

Tel.: 216935784; Fax: 216935790; E-mail: francisharvey@epfi.ch

2 Intitut für Länderkunde. Schongauer strasse 9. 04329 Leipzig, Germany.

Tel.: 341255 6500; Fax: 341255 6598; E-mail: wardenga@ ifl.uni-leipzig.de 
allemands de Hettner, Hartshorne n'interpréta pas non plus correctement la conception de Hettner. Mais, à la différence de beaucoup de géographes allemands, Harstshorne a bien compris certains aspects essentiels de la théorie de Hettner, tels l'approche relationnelle du concept de "région", le problème de la régionalisation et les rapports entre idiographie et nomothétie. La troisième partie est consacrée à montrer comment le débat entre Hartshorne et Schaefer a influencé la compréhension de la conception de Hettner par la géographie allemande des années soixante-dix.

Mots-clés: Hettner, Hartshorne, Géographie systématique, Géographie régionale, idiographie, nomothétie, débat Hartshorne-Schaefer.

Resumo: A LIGAÇÃO HETTNER-HARSTHORNE: RECONSIDERANDO O PROCESSO DE RECEPÇÃO E DE TRANSFORMAÇÃO DO CONCEITO DE GEOGRAFIA - Este texto trata do processo de recepção e de transformação de uma concepção de geografia a partir da conexão entre Hettner e Hartshorne. $\mathrm{Na}$ primeira parte resume-se o desenvolvimento e a estrutura da concepção de geografia de Hettner. Demonstra-se que as ideias correntes sobre as concepções geográficas de Hettner são o resultado de uma interpretação parcial, e em parte errónea, do seu pensamento. Na segunda parte analisa-se o modo como Richard Hartshorne recebeu os conceitos de Hettner. Tal como os seus contemporâneos alemães, Hartshorne não interpretou correctamente as ideias de Hettner. Mas, ao contrário de muitos geógrafos alemães, Harshorne compreendeu certos aspectos essenciais da teoria de Hettner como, por exemplo, a perspectiva relacional do conceito de "região", o problema da regionalização e as relações entre ideográfico e nomotético. Na terceira parte mostra-se como o debate entre Hartshorne e Hettner influenciou a compreensão das concepções de Hettner pela geografia alemã dos anos sessenta.

Palavras-chave - Hettner, Hartshorne, Geografia sistemática, Geografia regional, ideográfico, nomotético, debate Hartshorne-Schaefer.

The following contribution examines the process of reception and transformation of a geographic concept on the example of the Hettner-Hartshorne connection. We present the first results of a longer-term research project, whose focus is on the history of German-American discourse about methodological questions in the discipline. In this paper the emphasis is somewhat stronger on German geography. It will sketch the development and structure of Hettner's theoretical construction of geography and show how little Hettner was understood by German colleagues of the time. The second part illustrates how Richard Hartshorne received Hettner's concepts in his The Nature of Geography (1939). The third part examines the German reception of this reception, when in the 1970s following the Hartshorne-Schaefer debate, Hettner's construct was re-imported to Germany and was adapted to a new starting point for quantitative geography. 


\section{1 - HETTNER'S THEORETICAL CONSTRUCTION OF GEOGRAPHY}

According to most perceptions until now, two different perspectives have a role in Hettner's geographical construct, also referred to as schema or system. (Fig. 1). First, the perspective of general or systematic geography (Allgemeine Geographie). Its function is to examine each geofactor (Geofaktor) in isolation worldwide. The goal is nomothetic; this perspective looks for rules and laws. Second, the regional geography (Länderkunde) always examines a place or smaller part of the earth and thematisizes the relationship between geofactors with the goal of constructing the unmistakable uniqueness of a place or part of earth.

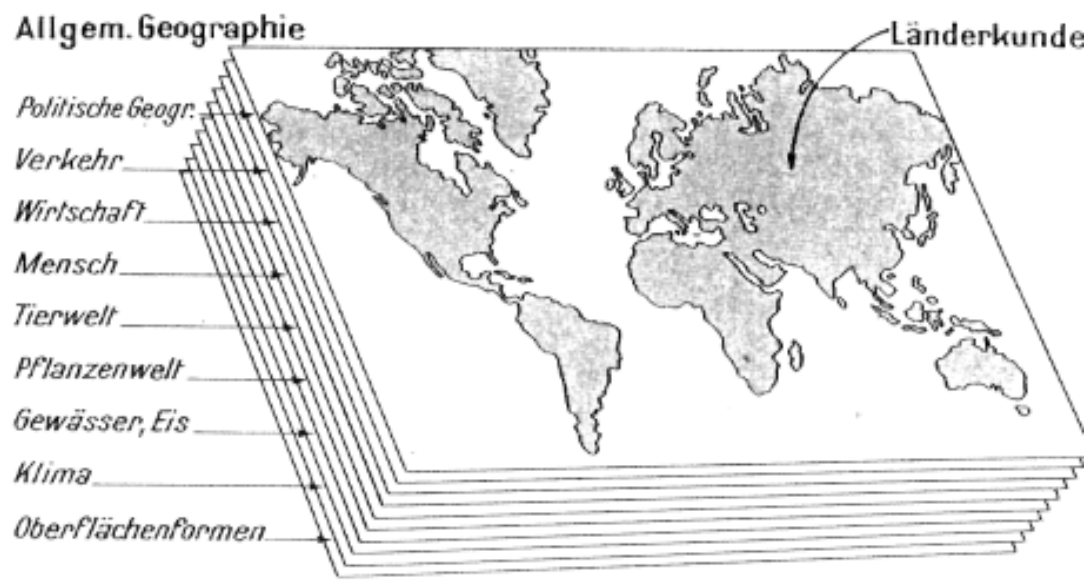

Fig. 1 - Hettner's geographical system according to Weight, 1957, p. 35

Fig. 1 - O sistema geográfico de Hettner segundo Weight, 1957, p. 35

This world-wide recognized image of Hettner's schema has a decided disadvantage. It is the result of a reception of Hettner's work, that only reproduces Hettner's construct partially and sometimes even distorted. This finding is the result of Ute Wardenga's dissertation, in which she set out to uncover the original meaning and actual structure of Hettner's geographical construct with the help of unpublished materials in the Hettner archives (WARDENGA, 1995). We will present his construct in more detail now, using a historical-genetic approach, which shows the development of Hettner's geographic construct.

All together there are six phases in the development of Hettner's construct.

During the first phase - 1859 until 1889 - Hettner developed his primary convictions. Already during his studies, he was certain that geography must be a regional science (Länderkunde). While studying he therefore took up a position in opposition to the official academic geography, that defined itself as a so-called general earth science and claimed to include all sciences that examined different aspects of 
planetary phenomena. In several periods of intense reflection, Hettner came to the conclusion at the end of 1880s that geography could only be a unitary discipline when it was no longer understood as a general earth science, but as a science with the goal of understanding the differences between earthly spaces (Differenz von Erdräumen). Accordingly he divided geography into two domains. In regional geography (Länderkunde) scientific questions were focused on the interrelationships between factors at a single place. The mission of the so-called "comparative regional geography" (Vergleichende Länderkunde), a term Hettner later synonymously used with systematic geography was, on the other hand, to trace the distribution of every single geofactor around the earth. The goal of this was to develop a clear basis for making the interrelationships involving a class of phenomena plain and so - according to him come to the previously neglected construction of spatial types (Raumtypen).

In the second phase - 1890 until 1900 - he sought to apply this concept and show its usefulness for geographic research. Among other things, he founded the Geographische Zeitschrift, planned a description of the earth consisting of fifty volumes, and called for a so-called "demographic base map" for human geography, which would be the basis for inductive, causally orientated human geographic research. Except for the 1895 grounded Geographische Zeitschrift, that quickly became one of the most read journals in geography, the other two research projects never went beyond planning. Both projects were attempts to introduce large research efforts to geography. Both failed because of the inability of contemporaries to organize collaborative research projects; there was little tolerance for such research networks. The consequences of their failing were catastrophic for the continued development of Hettner's construct, for it lost its empirical basis. From that point on, a gap began to open between research and representation in his thinking.

The third phase - 1901 until 1908 - was characterized by a withdrawal to himself. During this phase he specified his construct through a number of fundamental methodological publications, although a special kind of ambivalence remained. On one hand, Hettner's writing in this phase could be read as a research heuristic, on the other hand, it served as the logical preparatory work for a text book compendium, that he had planned since the end of the 1880s. This text book should encompass the whole system of geography, as he understood it. Already in these early publications, Hettner worked on a nominalistic concept of space. That is, he formulated the premise, that "spaces" did not exist for "a" geographer in "the" empirical reality (s) he examined, rather they were only constructed through the methodologically controlled regionalization as artifacts of geographic research and representation.

This relational object relation was not understood by Hettner's contemporaries (e.g. Otto Schlüter) and led to the first misinterpretations of Hettner's construct and to the first conflicts, that soon garnered Hettner the reputation of being an unspeakable polemiker.

The equally distributed weight on research and representation moved in the fourth phase from 1909 until 1919 due to the consideration of Davis' Cycle Theory and 
controversies resulting from the First World War with the new disciplinary position of geography. Especially through heeding Davis's work, Hettner slowly realized that his own construct, particularly where he referred to the so-called "explanatory description" (erklärende Beschreibung), was dominated by deductive elements. Additionally, he concentrated more and more on the writing of text books and overviews, which removed him increasingly from empirical research.

In the fifth phase - 1919 until 1927 - consequently followed the definitive shift in his construct to representational aspects. Even though Hettner was renowned at this point anywhere as the authority of geographic methodology, he was secretly well aware that neither the logic nor the structure of his thoughts was adequately understood by his contemporaries. Becoming emeritus in 1928 and the associated threat of losing power then right before his eyes, led him to take the decision to collect his published works for once and after re-working them and publish them under the title: "Die Geographie, ihre Geschichte, ihr Wesen und ihre Methoden" (Geography, Its History, Essence, and Methods).

At this point, we can not retrace individually the intricate and redundant threads of argumentation in this book. We will sketch the basic structure of his formal considerations.

Following Hettner's considerations, geography can only be a distinct science, when it considers reality from a chorological point of view. The term chorology does not refer to a method. Hettner meant the results of analyzing and recombining of materials, not the per se defined disciplinary field of interest. This means nothing else, than that geography was first constructed in the process of making geographic descriptions. Hettner understood countries, landscapes, and places as the artifacts of geographic thought processes. In terms of representation, he differentiated two different organizational approaches: first, the representation of the whole earth surface with emphasis on spatial differences of one factor. Second, he referred to the representation of smaller spaces, as units, with an emphasis on examining causal relationships between different factors. Until this point the previously discussed graphical presentation of Hettner's schema agrees with these principles. However, it does not include the key problem.

The key problem for Hettner was the regionalization, the subdivision of the earth's surface. First, he differentiated between completely formal interrelationships of similarity and difference on one hand, and between positional relationships and other relationships on the other hand. The results of the first systematization were spatial connected complexes and systems (e.g. watersheds or urban systems). The result of the second systematization were spatially unassociated classes and types (e.g. classes of geological strata, or climate types).

The logical distribution of material in Hettner's planned text books looked like this: In the context of comparative regional geography (Vergleichende Länderkunde) each global individual system would be ordered by geofactors and described. This included, e.g., the global tectonic system, the climate and soils of the earth, flora and fauna, the global urban system, international traffic and economics. The goal of this 
description was the construction of spatial classes and types as well as spatial complexes. At a logical level this operation corresponds to a differentiation. In a second step, the differentiated units, still separated by geofactor were integrated to primary spaces (Grossräume). Each of these large spaces would then undergo a second differentiation, in which tertiary complexes, classes, and types would be identified, which, in turn, would be integrated as secondary spaces at a scale level corresponding to countries (Länder). Shifting between differentiation and integration could be carried on until there was nothing left to be differentiated. Only the place, a completely unique individual, would result.

It is easy to see, that Hettner's construct involved going from the abstract to the concrete like a series of maps of increasing scale at different levels of generalization. Second, it is apparent, how strong Hettner moved away from commonly accepted concepts in general geography and Länderkunde. While the traditional sub-field groupings in geography builds on the premise that general geography deals with the nomothetic components of the discipline and regional geography examines the idiographic part of the discipline, Hettner's construct has much more subtle differences. Moving between differentiation and integration leads to shifting positions between Nomothesis and Idiography. Finally, the goal of geography is idiographic, because the nomothetic orientated constructions are merely carried out to reduce complexity.

Hettner's hope, that his contermporaries would grasp his construct through the collected publication of his oevrage was not fulfilled, because he remained too trapped in his own world of thoughts, did not provide a clear string of arguments, and the terminology was not coherent. His book therefore led to more to confusion instead of explication. Accordingly, the years 1929 until 1941, the sixth phase, were characterized by the hopeless attempt to defend his construct from increasingly abstruse distortions.

This began with the nasty and pointless quarrels revolving around the so-called "länderkundliche" or "Hettnersche Schema." Basically, this controversy arose because Hettner's critics, most of all Hans Spethmann, did not understand Hettner's theory of representation, nor the relational object relationship, upon which Hettner's system was based. As a result, contradictions were interpreted into his construct, that did not really exist. By the time Hitler and the Nazi's took power, Hettner, whose grandmother was Jewish, was pushed more and more into a defensive position and had to watch powerless as he became the object of belligerent rendition of historiography, that attacked him with polemic arguments.

From that point on everything failed what he did to explain his construct yet again. A series of handbooks on "Vergleichende Länderkunde," planned since 1889 and completed in the beginning of the 1930s, was critically reviewed, because nobody understood his theoretical reflections regarding representation. No publisher could be found for another book about the methodology of geography. Finally, he was left with only a torso from the original four volumes conceived for "Allgemeine Geographie des Menschen. "To that point in time, when Richard Hartshorne published The Nature of Geography, Hettner was written off by most German academic geographers as an "liberal positivist." He was no longer an authority for orientation: his geography 
represented the image of a by then voided, causally directed phase in the discipline.

\section{2 - THE RECEPTION OF HETTNER'S CONCEPTS THROUGH RICHARD HARTSHORNE}

Alfred Hettner is the most quoted German-language geographer in Hartshorne's The Nature of Geography. Both scientists did not know each other personally, written correspondence was very scarce: apparently only two letters were exchanged. Even if Hartshorne considered translating Hettner's book on methodology (1927), The Nature of Geography, although based on Hettner's work, is an independent treatment of contemporary developments in geography. This independence has not been considered sufficiently in the history of science. Indeed, Hartshorne follows Hettner's trails in the introductory chapters dealing with the history of geography; the "Deviations from the Course of Historical Development" and "The Justification for the Historical Concept of Geography as a Chorographic Science" correspond to the chain of arguments from sections 1 through 3 of Hettner's second chapter. In this chapter Hettner lays out "The Essence and Roles of Geography". Contrary to Hettner, Hartshorne intensively examines the German concept of Landschaft (landscape), which was built into German academic geography since the 1920s and originated in pedagogy of secondary education. Much stronger than Hettner - who was very critical of landscape geography, and even at some point sharply rebuked the concept - Hartshorne's reflections concerning e.g. "The Concept of the Region as a Concrete Unit Object" and "Methods of Organizing the World into Regions" are characterized by terminology coming from this concept, e.g. "organism," "harmony," and "rhythm". In this sense, Hartshorne's methodology was more in tune with the discussions at that point. It is also, in spite of occasionally mixed in side remarks towards Sauer, more rational and open in presenting other positions. However, Hettner's methodology is explained in more polemic argumentation when discussing other positions, for example those of Otto Schlüter, Siegfried Passarge, William Morris Davis and Ewald Banse.

We cannot be critical of Hartshorne's failure to grasp Hettner's construct. Just as little as German contemporaries, he could not see through the different layers of text in development, that Hettner's writing dealt more with a theory of geographic representation than a methodology for geographic research. What Hartshorne understood - in contrast to most of the German speaking contemporaries - was Hettner's relational approach to the regional concept. For example, Hartshorne writes on p. 429 in The Nature of Geography, completely following Hettner's approach, "regions (are no) 'entitites' ... unitary or concrete objects." On p. 460 he states: "The region itself, we find, is not determined in nature or in reality. We cannot hope to 'discover' it by research, we can only seek the most intelligent basis ... for determining its limits - in general, for dividing the entire world into regions". This means: "The question as to which criteria shall be chosen for determining regions likewise finds no answer in nature ... the choice must be made by the geographer, according to his subjective judgment of their importance. Consequently one cannot speak of true and false regional divisions, but only of purposeful and non-purposeful. There is no universally valid division, which 
does justice to all phenomena; one can only endeavor to secure a division with the greatest possible advantages and the least possible disadvantages" (p. 466). Consequently he explains: "The area itself is not a phenomenon, any more than a period of history is a phenomenon; it is only an intellectual framework of phenomena, an abstract concept which does not exist in reality" (p. 571).

Just like Hettner, Hartshorne was not of the opinion that chorographically orientated geography was just an idiographic, exceptionalist science. As his German colleague, he recognized the problem of regionalization as one of the main methodological problems of geography (see HARTSHORNE, 1939: 537ff). For Hartshorne the search for rules and laws as well as the construction of types had an undeniable value in geography. However, they were not the final goals of regional geographic descriptions, but were, citing Hettner, "always a means for a purpose" (HETTNER, 1927: 224), fundamentally the purpose of reducing the complexity of reality.

Against this background, it is all the more surprising to which degree Hartshorne was misunderstood by Schaefer and his followers.

Since the Hartshorne-Schaefer debate has already been quite well examined e.g. through the 1989 book Reflections on Richard Hartshorne's The Nature of Geography, edited by Entrikin and Brunn, we will close by exploring the question how the understanding of Hettner's concept in German geography of the 1970's was influenced by the Hartshorne-Schaefer debate.

\section{3 - HETTNER - HARTSHORNE-SCHAEFER - HETTNER AND GERMAN GEOGRAPHY}

The Hartshorne-Schaefer debate was first taken up in German geography when in the beginning of the 1970s the quantitative revolution had successfully effected Central Europe and made the old, idiographic approach of Länderkunde and Landschaftskunde obsolete. In a then well-received reader put out by Dietrich Bartels in 1970, Schaefer's "Exceptionalism in Geography" was published next to essays from Gould, Haggett, Yeates, Hägerstrand, Berry, Olsson and Nystuen. This left its mark on a whole generation of geography students. Even though Heinrich Schmitthenner had pointed to Hettner's constructivist approach in the 1950s and had taken up Hettner's arguments against an unreflective-holistically driven landscape geography (SCHMITTHENNER, 1954), Hettner was stylized in the 1960s as the leading methodologist of landscape geography. This made him into something that he never was. On this point, critique of Hettner came from some forces of renewal in geography that wanted to move away from an exceptionalistic orientated geography to a geography that, as a methodologicaltheoretically controlled discipline sought after rules and laws in Schaefer's sense. How convoluted the situation became by the end of the 1970s can be shown in the statements of Hans-Dietrich Schultz, who examined in his dissertation the methodology of German language geography from 1800 until 1970 (SCHULTZ, 1980). Schultz could make clear again through the successions of interpretations that Hettner used the term Landschaft from a nominalistic perspective, but this made Hettner's writings appear even more contradictory. Then, how could the fact be explained, that he was 
completely for Länderkunde before 1900, but later in the 1920s and 1930s, as regional geography established itself in universities around the landscape concept, reacted with a series of polemic work that was completely against Länderkunde? On this background, Hettner was a clearly quarreling man, who fighted against everything that did not reproduce his own, obviously convoluted methodology.

Only in the 1980s did a more moderate evaluation begin to set itself through. Gerhard Bahrenberg, one of the strongest supporters of the quantitative revolution acknowledged for example in 1987 that a "certain rehabilitation and positive evaluation of Hettner" would be "not only desirable, but probably overdue" (BAHRENBERG, 1987: 226).

The first step had already been taken by J. F. Ostermeier in his dissertation published in 1986. In this work he examined Hettner's understanding of the position of geography in the systems of sciences as well as his relations to Kant and NeoKantianism. He was able to show that Hettner's scientific system was not at all that original as Hettner claimed during the course of his whole life. The division Hettner used between natural and social sciences (Natur- und Geisteswissenschaften) and the subdivision in abstract and concrete sciences corresponded to contemporary concepts. The same applied to the bridge function of geography. Ostermeier also uncovered the historiographically described agreement between Hettner's and Kant's scientific systems as a historical mythos, that came from a negative, superficial variant reading of Kant's "Physische Geographie", represented above all by Schaefer and Harvey. Hartshorne's positive variant followed the goal of helping geography to a more esteem. Ostermeier's study is mostly attractive because it sheds an important light on the condition of disciplinary historiography, which was deeply caught up in misunderstandings, erroneous interpretations, and wrong judgements.

Without doubt, it is the right of every generation, to interpret the traditions of scientific disciplines from their perspective. That the questions asked are influenced by contemporary perspective is well known. The degree however to which historical images in geography have been adapted to the current intellectual fashion and instrumentalized then as weapons in the process of pushing through new ideas, should give us grounds to think, considering that the case of Hettner's construct does not appear to be an exception.

\section{BIBLIOGRAPHY}

BAHRENBERG, G. (1987) - Über die Unmöglichkeit von Geographie als "Raumwissenschaft". Gemeinsamkeiten in der Konstituierung von Geographie bei A. Hettner und D. Bartels. In BAHREnBerG, G. et al. (eds.) - Geographie des Menschen. Dietrich Bartels zum Gedenken. Bremer Beiträge zur Geographie und Raumplanung, 11. Selbstverlag des Geographischen Instituts der Universität Bremen, Bremen: 225-239.

BARTELS, D. (ed.) (1970) - Wirtschafts- und Sozialgeographie. Kiepenheuer \& Witsch, Köln - 
Berlin.

ENTRIKIN, J. N.; S. D. BRUNN (eds.) (1989) - Reflections on Richard Hartshorne's The Nature of Geography. Occasional Publications of the Association of American Geographers, Washington.

HARTSHORNE, R. (1939) - The nature of geography: A critical survey of current thought in the light of the past. Annals of the Association of American Geographers, 39: 173-658.

HETTNER, A. (1927) - Die Geographie, ihre Geschichte, ihr Wesen und ihre Methoden. Hirt, Breslau.

OSTERMEIER, J. F. (1986) - De opvattingen van Alfred Hettner (1859-1941) over de plaats van de geografie in het system van de wetenschappen. Een bijdrage tot zijn intellectuele biografie. Proefschrift, Nijmegen.

SCHAEFER, F. K. (1953) - Exceptionalism in Geography. A Methodological Examination. Annals of the Association of American Geographers, 43: 226-249.

SCHMITTHENNER; H. (1954) - Zum Problem der allgemeinen Geographie und der Länderkunde. Münchener Geographische Hefte, 4. Lassleben, Kallmünz - Regensburg.

SCHULTZ, H. D. (1980) - Die deutschsprachige Geographie von 1800 bis 1970. Ein Beitrag zur Geschichte ihrer Methodologie. Abhandlungen des Geographischen Instituts Anthropogeographie, 29. Selbstverlag des Geographischen Instituts der Freien Universität Berlin, Berlin.

WARDENGA, U. (1995) - Geographie als Chorologie. Zur Genese und Struktur von Alfred Hettners Konstrukt der Geographie. Steiner, Stuttgart.

WeIGT, E. (1957) - Die Geographie. Eine Einführung in Wesen, Methoden, Hilfsmittel und Studium. Das Geographische Seminar. Westermann, Braunschweig. 